\title{
The Utilization of the Cobb-Douglas Production Function for Analyzing Indonesia's and Malaysia's Economic Growth
}

\author{
Elis Ratna Wulan 1 \\ ${ }^{1}$ Sunan Gunung Djati, State Islamic University, Bandung Indonesia \\ E-Mail: elis_ratna_wulan@uinsgd.ac.id
}

\begin{abstract}
This paper presents the utilization Cobb-Douglas production function in its classical form for analyzing Indonesia's and Malaysia's economic growth in relation to the intensity of using capital and labour as determinants of the production. Production function appropriate to describe the economy Malaysia and Indonesia with the condition proportion to the population of productive age are at a relatively constant rate and the increasingly advanced technology are: $Y=F(H, K)=$ $A H^{\alpha} K^{\beta}$. With $\mathrm{A}$ is technological progress and $\mathrm{H}$ is the total population of productive age. The model can be used to determine the productivity of the economy of Malaysia and Indonesia. Further research can be done by considering the economic system of a country.
\end{abstract}

Keywords: Production function, capital, labour.

\section{A. INTRODUCTION}

Research on the function of production began in 1928. At that time Charles Cobb and Paul Douglas published the results of research on the modeling of the growth of the U.S. economy over the period 1899 to 1922 . The results stated that production is determined by the amount of labor involved and the amount of capital invested. The concept is known as the Cobb Douglass function (Stewart, 2003).

Economists developed theories based development to a production capacity human labor in the process of development, known as an investment in human capital (Lisnawati, 2008). The concept was to support economic growth and have started to think about since the time of Adam Smith in 1776, Heinrich von Thunen in 1875 and other classical theorists before the 19th century that emphasized the importance of investment in human skills. This theory is based on the consideration that the most efficient way of doing the national development of a country depends on improving the ability of society including education. The concept of education as an investment has grown rapidly and is increasingly believed by every state that development of the education sector is a key prerequisite for the growth of other development sectors. Indicator in the contribution of education to economic growth is making a relationship between educations an employment. This reasoning is based on the assumption that the education is a human capital in the era of industrialization in modern society. Education is a form of national investment to improve the quality of human resources is needed in a modem economy. Educational investment is expected to generate an increase in prosperity and wider opportunity in real life (Permatasari, 2010).

Human capital theory assumes that formal education is an important instrument to produce a society that has a high productivity. Educational intervention in the economy is an effort to prepare economic actors in carrying out the functions of production. The intervention of the production function in the form of labor supply is included with labor productivity and higher education 
(Lisnawati, 2008).

Mathematical models designed to study systems that arise in real problems. Description process of the system is called mathematical modeling (Meyer, 1984). This paper examines the Cobb Douglass production appropriate to describe the economy of Malaysia and Indonesia. This function is reviewing two factors, labor and capital.

\section{B. METHODOLOGY}

The method used in the writing of this paper is the study of literature by examining a variety of $Y=F(H, K)=A H^{\alpha} K^{\beta}$, journals and books related to the Cobb Douglass production function model.

The production function is a mathematical relationship of certain products depending on the number of inputs (Permatasari, 2010). The Cobb Douglass production function is a production function, which states that production, is determined by the amount of labor and the amount of invested capital (Stewart, 2003). The form of the Cobb Douglass function is:

With $F(H, K)$ is the total output, $\mathrm{H}$ is labor, $\mathrm{K}$ is capital, and $\mathrm{A}, \mathrm{IX}$, is a constant which is the parameter value of the factor $\mathrm{H}$ and $\mathrm{K}$

\section{RESULT AND DISCUSSION}

\section{Mathematical Modelling}

The mathematical model is a model developed by mathematical concepts such as constants, variables, functions, equations, and inequalities (Meyer, 1984). The design of mathematical models carried out to study the systems that arise in real problems. Description process of the system is called the mathematical modelling.

The making of notation from a real condition to specific variables includes independent variables and dependent variables. It is intended to make it easier to model and analyze it.

\section{Production Function}

The production function can be defined as follows (Ferguson and Gould, 1976):

a. A schedule (table or mathematical equations) that shows the total amount of output produced one of several inputs, resulting from existing technology.

b. A mathematical relationship that describes a way, with a certain number of inputs used. A production function gives a description of the expected results when production factor combined.

The production function can be used to study market economy. One of the production functions is Cobb Douglass production function. The production function in the long run will reduce the Cobb Douglass production function. Cobb Douglass functional form of the production is generally used to represent the relationship of input to output. This was stated by Wicjsell in the year 1851-1926 and studied statistically by Charless Cobb and Paul Douglass in 1928 (Jones, 2005). 


\section{Population Growth Model}

Basic growth model by Lan in Permatasari (2010) is: $\frac{d N}{d t}=a N$

The relationship is known as Law of Malthus. Integration results of equation (1) is obtained:

$$
N(t)=N_{0} e^{a t}
$$

$\mathrm{N}_{0}$ is the initial population and $\mathrm{a}$ is the rate of population growth. Equation (2) applies when there is a number in a population of infinite resources and there is no competition between individuals. If there are limited resources, so that the population needs to be controlled, then the model will be used as follows:

$$
\frac{d N}{d t}=N(a-b N)
$$

$b$ is a factor inhibiting the growth rate, in order to obtain equation (4) the following:

$$
N(t)=\frac{\frac{a}{b}}{1+\left(\frac{a-b N_{0}}{b N_{0}}\right) e^{-a t}}
$$

\section{Capital Growth Model}

Referring to the basic growth model in equation (1), the growth rate of capital/ investment is proportional to the amount of capital outstanding

$$
\frac{\Delta K}{\Delta t} \approx K
$$

so the growth rate of capital at any time is the result of a constant times the capital that can be expressed in equation (5) as follows:

$$
\frac{d K}{d t}=r K
$$

integration results of equation (5) is

$$
K(t)=K_{0} e^{r t}
$$

$\mathrm{K}_{0}$ is the initial capital and $\mathrm{r}$ is the growth rate of capital is constant.

\section{Analisys of Research Findings}

\section{a. Population Growth in Malaysia and Indonesia}

Model of population growth in Malaysia and Indonesia can be presented as equation (3). The model is in accordance with the conditions in Malaysia and Indonesia to implement a policy of two children is a government program to control the rapid population growth in Malaysia and 
Indonesia, bringing the toatal number of productive age population can be maintained which would indirectly impact on productivity and economic productivity.

\section{b. Capital Growth}

Economic policy in Malaysia and Indonesia is pressing interest rates. The interest rate is the interest level begin with a basic concept of compound interest (Chiang, 2005). In general, for interest rate $\mathrm{m}$, obtain capital as follows:

$$
K(m)=\left(1+\frac{1}{m}\right)^{m}
$$

where $\mathrm{m}$ is the frequency of compounding interest in one year.

From equation (7) if the interest rate in a year divided in $m$ that is not so huge capital to continue to grow and form a pattern of a snowball at the end of the first year:

$$
\lim _{m \rightarrow \infty} K(m)=\lim _{m \rightarrow \infty}\left(1+\frac{1}{m}\right)^{m}=e
$$

Numbers e can be interpreted in economics as the basis of the economic growth (Permatasari, 2010).

To a certain interest rate is $r$, the amount of capital obtained by equation (7) and equation (8) is:

$$
K(m)=K_{0}\left(1+\frac{r}{m}\right)^{m t}
$$

algebraic manipulations performed, in order to obtain:

$$
K(m)=K_{0}\left[\left(1+\frac{r}{m}\right)^{\frac{m}{r}}\right]^{r t}
$$

When $\mathrm{m} \rightarrow \infty$, then:

$$
\lim _{m \rightarrow \infty} K(m)=K_{0} e^{r t}
$$

Equation (11) is the equation of the growth rate of capital.

Implementation of the policy of low interest rates had a positive impact on the economy of the country and is expected to trigger investment by the public so that they can generate economics productivity in Malaysia and Indonesia.

\section{c. Cobb Douglass Production Function}

The production function is a mathematical relationship of certain products depending on the number of inputs (Permatasari, 2010). The Cobb Douglass production function is a production 
function which states that production is determined by the amount of labor and the amount of invested capital (Stewart, 2003). The form of the Cobb Douglass function is:

$$
Y=F(H, K)=A H^{\alpha} K^{\beta}
$$

with $F(H, K)$ is the total output, $H$ is labor, $K$ is capital, and $A, a, \beta$ is a constant which is the parameter value of the factor $\mathrm{H}$ and $\mathrm{K}$.

The first assumption is valid at Cobb Douglass function is the marginal productivity of capital is proportional to the amount of output per unit of capital $\left(\frac{F}{K}\right)$. The assumption can be expressed by:

$$
\frac{\partial F}{\partial K}=\beta \frac{F}{K}
$$

According to equation (12), for a constant $\beta$, if $H$ is constant $\left(H=H_{0}\right)$ then equation (13) becomes an ordinary differential equation, namely:

$$
\frac{d F}{d K}=\beta \frac{F}{K}
$$

Equation (14) can be solved, in order to obtain the solution:

$$
F\left(H_{0}, K\right)=c_{1}\left(H_{0}\right) K^{\beta}
$$

with $\mathrm{c}_{1}$ is a constant and is expressed as a functon ofi $\mathrm{H}_{0}$ (initial number of workers).

The second assumption applies to Cobb Douglass function is the marginal productivity of labor is proportional to the amount of output per unit of labor $\left(\frac{F}{H}\right)$. The assumption can be expressed by:

$$
\frac{\partial F}{\partial H}=\alpha \frac{F}{H}
$$

According to equation (12), for a constant $\alpha$, if $\mathrm{K}$ is constant $\left(\mathrm{K}=\mathrm{K}_{0}\right)$ then equation (16) becomes an ordinary differential equation, namely:

$$
\frac{d F}{d H}=\alpha \frac{F}{H}
$$

Equation (17) can be solved, in order to obtain the solution: $F\left(H, K_{0}\right)=c_{2}\left(K_{0}\right) H^{\alpha}$

with $\mathrm{c}_{2}$ is a constant and is expressed as a function of $\mathrm{K}_{0}$ (initial capital amount).

By using equation (15) and equation (18) is obtained: $Y=F(H, K)=A H^{\alpha} K^{\beta}$ 
as the general form of the Cobb Douglass function corresponding to equation (12). Production function appropriate to describe the economy of Malaysia and Indonesia with the condition proportion to the population of productive age are at a relatively constant rate and the increasingly advanced technology is a technological progress with $\mathrm{A}$ and $\mathrm{H}$ is the total population of productive age .

\section{d. Conclusion}

Production function appropriate to describe the economy Malaysia and Indonesia with the condition proportion to the population of productive age are at a relatively constant rate and the increasingly advanced technology are: $Y=F(H, K)=A H^{\alpha} K^{\beta}$, with $\mathrm{A}$ is technological progress and $\mathrm{H}$ is the total populationof productive age. The model can be used to determine the productivity of the economy of Malaysia and Indonesia. Further research can be done by considering the economic system of a country . 


\section{References}

Chiang, A.C. and Kevin, W. (2005). Fundamental Methods of Mathematical Economics $4^{\text {th }}$ Edition. New York: Mc Graw Hill.

Ferguson and Gould. (1976). Microeconomic Theory. USA: Richard D. Irwink.

Jones, S.C.I. (2005). The Shape of Produtction Function and Direction of Technical Change. The Quarterly Journal of Economics. May 2005, 517-549.

Lisnawati, C. (2008). Aspek Ekonomi dalam Pendidikan. Available at: http://educare.e-fkipunla.net [September 25, 2012].

Meyer, W., J. (1984). Concept of Mathematical Modelling. Mc Graw Hill Book Company.

Permatasari, R. (2010). Model Fungsi Produksi Lucas dan Keberhasilan Pertumbuhan Ekonomi di China. Not published. Surakarta: FMIPA Universitas Sebelas Maret.

Stewart. (2003). Kalkulus Edisi 4 jilid 2.Jakarta: Erlangga. 